\title{
THE PASSAGE OF AMMONIA ACROSS THE BLOOD-BRAIN- BARRIER AND ITS RELATION TO BLOOD pH
}

\author{
BY KENNETH S WARREN AND DAVID G. NATHAN 1 \\ (From the Laboratory of Tropical Diseases, National Institute of Allergy and Infectious \\ Diseases, and the General Medicine Branch, National Cancer Institute, National \\ Institutes of Health, Bethesda, Md.)
}

(Submitted for publication March 19, 1958; accepted July 31, 1958)

Ammonium salts have been shown to have significantly different toxicities $\left(L D_{50}\right.$ 's) when administered intravenously under controlled conditions (1). This differential toxicity appeared to be related to the change in blood $\mathrm{pH}$ induced by each salt.

The normal blood $\mathrm{pH}$ (7.4) is close enough to the $\mathrm{pKbh}$ of ammonia, ${ }^{2}$ approximately 8.90 at $37^{\circ}$ C. (2), so that any change in blood $\mathrm{pH}$ would significantly affect the ratio of unionized $\left(\mathrm{NH}_{3}\right)$ to ionized $\left(\mathrm{NH}_{4}^{+}\right)$ammonia. Based on two factors, the greater tissue permeability to unionized particles (3-6) and the marked limitation of passage of ionized particles by the blood-brain-barrier (7-9), it was postulated that a greater percentage of a given dose of ammonia might enter the brain as the blood $\mathrm{pH}$ rose because of an increase in the amount present as $\mathrm{NH}_{3}$.

In order to test this hypothesis, blood $\mathrm{pH}$ and simultaneous blood and brain ammonia concentrations were determined following the intravenous administration of $\mathrm{LD}_{50}$ doses of several ammonium salts. This was done on the assumption that since the primary toxic effect of ammonia appeared to be located in the central nervous system the brain levels would be relatively similar despite different $\mathrm{LD}_{50}$ dosages of each salt.

\section{MATERIALS AND METHODS}

$\mathrm{LD}_{50}$ doses (1) of five ammonium salts dissolved in 1 $\mathrm{ml}$. of isotonic saline were rapidly injected into the tail veins of 18 to $22 \mathrm{Gm}$. Swiss albino mice. Heart blood was drawn at various intervals after injection. Immediately thereafter the mice were frozen in liquid nitrogen.

The blood ammonia concentration in a protein free preparation of 0.5 to $1.0 \mathrm{ml}$. of heart blood was determined by a microdiffusion technique (10). The control blood

\footnotetext{
1 Present address: Peter Bent Brigham Hospital, Boston, Mass.

2 The term "ammonia" refers to ammonium ion plus free ammonia.
}

ammonia concentration was $0.6 \mu \mathrm{g}$. per ml. Brain ammonia levels were determined by a modification (11) of this technique utilizing the entire frozen mouse brain. The brain was shelled out, ground to a fine powder with cold instruments, and added to $3 \mathrm{ml}$. of 3 per cent cold trichloracetic acid. The tubes were weighed before and after the brain was added, and were centrifuged at $3^{\circ} \mathrm{C}$. The ammonia concentration of a $1 \mathrm{ml}$. aliquot of the supernatant was then measured by the previously mentioned method (10) and the brain ammonia calculated from these data. Glutamine amide error was a constant 22 per cent of the control ammonia concentration of $4.0 \mu \mathrm{g}$. per $\mathrm{Gm}$. of wet brain.

The $\mathrm{pH}$ of heparinized heart blood obtained from live unanaesthetized animals was immediately determined at room temperature with a Beckman Model GS meter equipped with a $290-80$ blood electrode.

Electrocardiograms were obtained from pentobarbital anaesthetized mice during the intravenous injection of $\mathrm{LD}_{\mathrm{s0}}$ doses of the five ammonium compounds. Electrodes were implanted subcutaneously as limb leads, and the recording was made on a Sanborn polyviso recorder.

\section{RESULTS}

Mice injected with ammonium chloride immediately demonstrated agitated movements followed rapidly by the onset of coma. They either died following a tonic convulsion, within 15 minutes, or regained consciousness after 30 to 40 minutes. The other ammonium salts killed in a similar manner, but death occurred more rapidly and those which recovered did so in progressively less time. For instance, many mice injected with ammonium carbonate died within 15 seconds. This change in killing time paralleled the effect of the salts in increasing blood alkalinity.

Control animals injected with $1 \mathrm{ml}$. of isotonic saline, and with dosages of sodium salts equimolar to those of the ammonium salts, exhibited no signs of toxicity.

Since toxic symptoms appeared to be largely of cerebral origin, the passage of ammonia from the blood stream into the brain was studied. Follow- 


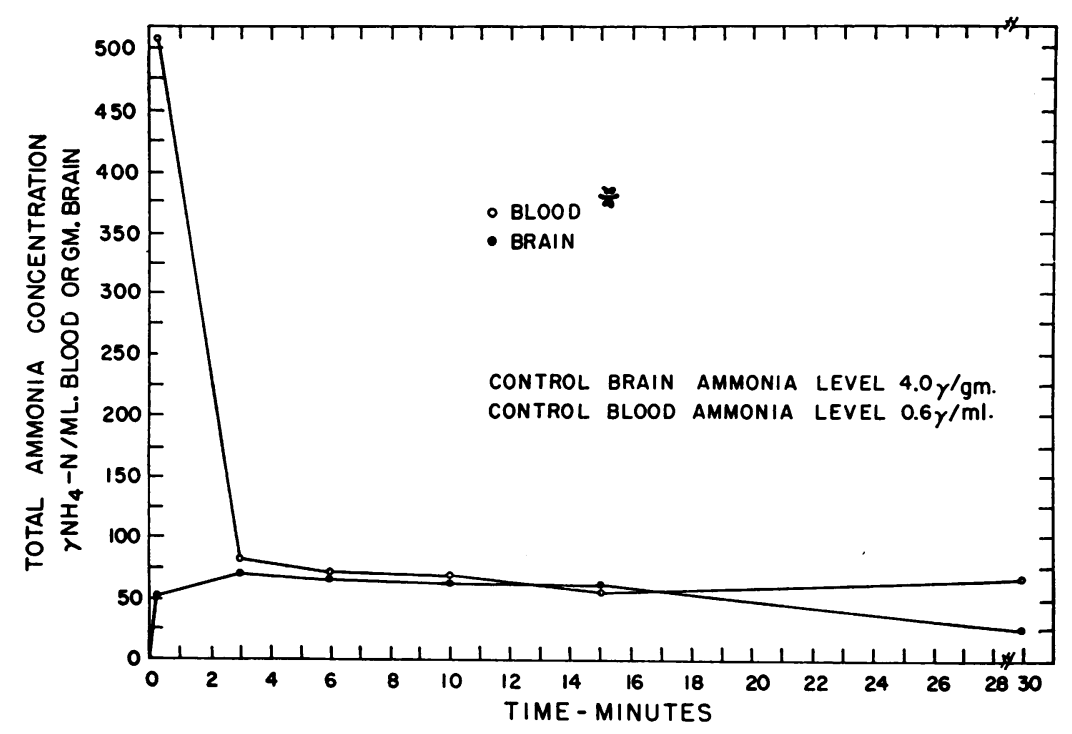

Fig. 1. Blood and Brain Ammonia Levels Following the Intravenous InJeCtion of $1,886 \gamma$ of $\mathrm{NH}_{4}-\mathrm{N}$ IN THE FoRM OF $\mathrm{NH}_{4} \mathrm{CL}$ ( $\mathrm{LD}_{60}$ Dose)

* Three to six determinations at each time interval.

ing the injection of an $\mathrm{LD}_{50}$ dose of ammonium chloride simultaneous blood and brain samples were taken at intervals up to 30 minutes (Figure 1). The earliest blood samples obtainable (at 22 seconds) revealed an ammonia concentration of $501 \mu \mathrm{g}$. per ml. At 3 minutes it had decreased to $82 \mu \mathrm{g}$. per $\mathrm{ml}$. During the following 27 minutes an insignificant fall occurred.

Analysis of the simultaneous brain samples as shown in Figure 1 revealed an extremely rapid initial increase in ammonia level. Although the maximum brain ammonia level recorded was attained in 180 seconds, 72 per cent of that level was achieved by 22 seconds. At 30 minutes the brain ammonia concentration had appreciably decreased.

The $\mathrm{NH}_{4}-\mathrm{N}$ content of the $\mathrm{LD}_{50}$ dose of ammonium chloride, acetate, bicarbonate, carbonate, and hydroxide varied inversely with their alkalinizing effect on the blood $\mathrm{pH}$ (Table I). The differences in $\mathrm{NH}_{4}-\mathrm{N}$ necessary to produce an $\mathrm{LD}_{50}$ were even more striking when blood levels were measured 22 seconds following the injection of the compounds. As the alkalinity of the blood increased, the ammonia appeared to pass from the blood stream more rapidly: 80 per cent of ammonium chloride remained in the blood at 22 seconds, whereas only 36 per cent of ammonium carbonate and hydroxide remained.

TABLE I

Simultaneous blood and brain ammonia levels 22 seconds following the intravenous administration of $L D_{\text {so }}$ doses of ammonium salts

\begin{tabular}{|c|c|c|c|c|c|c|c|}
\hline $\begin{array}{l}\text { Ammonium } \\
\text { compounds }\end{array}$ & $\begin{array}{c}\text { Blood } \\
\text { pH }\end{array}$ & $\begin{array}{l}\text { Amount } \\
\text { injected }\end{array}$ & $\begin{array}{l}\text { No. of } \\
\text { obser- } \\
\text { vations }\end{array}$ & $\begin{array}{c}\text { Blood } \\
\text { ammonia }\end{array}$ & $\frac{\text { Blood ammonia }}{\text { Ammonia injected } / 3 \dagger}$ & $\begin{array}{c}\text { Brain } \\
\text { ammonia }\end{array}$ & $\frac{\text { Brain ammonia }}{\text { Blood ammonia }}$ \\
\hline & & $\begin{array}{l}\text { Mg. } N H_{1}-N \\
\text { in } 1 \mathrm{mll} .\end{array}$ & & 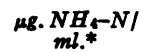 & & 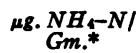 & \\
\hline $\begin{array}{l}\text { Chloride } \\
\text { Acetate } \\
\text { Bicarbonate } \\
\text { Carbonate } \\
\text { Hydroxide }\end{array}$ & $\begin{array}{l}7.05 \\
7.23 \\
7.48 \\
7.58 \\
7.74\end{array}$ & $\begin{array}{r}1,886 \\
1,748 \\
1,415 \\
1,250 \\
707\end{array}$ & $\begin{array}{l}8 \\
7 \\
9 \\
6 \\
9\end{array}$ & $\begin{array}{c}501 \pm 28 \\
434 \pm 30 \\
272 \pm 20 \\
151 \pm 19 \\
85 \pm 5\end{array}$ & $\begin{array}{l}0.80 \\
0.74 \\
0.58 \\
0.36 \\
0.36\end{array}$ & $\begin{array}{l}54 \pm 5 \\
60 \pm 5 \\
62 \pm 3 \\
45 \pm 2 \\
34 \pm 3\end{array}$ & $\begin{array}{l}0.11 \pm .012 \\
0.14 \pm .015 \\
0.23 \pm .020 \\
0.30 \pm .040 \\
0.40 \pm .042\end{array}$ \\
\hline
\end{tabular}

* Mean plus or minus standard error.

† 3 equals approximate blood volume $(2 \mathrm{ml}$.) plus volume injected $(1 \mathrm{ml}$.). 
TABLE II

Ammonia passage into the brain in the first minute following intravenous administration of $L D_{50}$ doses *

\begin{tabular}{|c|c|c|c|c|c|}
\hline \multirow{2}{*}{$\begin{array}{l}\text { Seconds } \\
\text { after } \\
\text { injection }\end{array}$} & $\begin{array}{c}\text { Ammonium } \\
\text { chloride } \\
\left(1,886 \mu \mathrm{g} . \mathrm{NH}_{4}-\mathrm{N}\right)\end{array}$ & $\begin{array}{c}\text { Ammonium } \\
\text { acetate } \\
\left(1,748 \mu \mathrm{g} . \mathrm{NH}_{4}-\mathrm{N}\right)\end{array}$ & $\begin{array}{c}\text { Ammonium } \\
\text { bicarbonate } \\
\left(1,415 \mu \mathrm{g} . \mathrm{NH}_{4}-\mathrm{N}\right)\end{array}$ & $\begin{array}{c}\text { Ammonium } \\
\text { carbonate } \\
\left(1,215 \mu \mathrm{g} . \mathrm{NH}_{4}-\mathrm{N}\right)\end{array}$ & $\begin{array}{c}\text { Ammonium } \\
\text { hydroxide } \\
\left(707 \mu \mathrm{gg} . \mathrm{NH}_{4}-\mathrm{N}\right)\end{array}$ \\
\hline & \multicolumn{5}{|c|}{ Brain ammonia, $\mu g . / \mathrm{Gm}$. } \\
\hline $\begin{array}{r}5 \\
30 \\
60\end{array}$ & $\begin{array}{l}35 \pm 2.2 \\
42 \pm 2.8 \\
43 \pm 1.1\end{array}$ & $\begin{array}{l}33 \pm 1.8 \\
37 \pm 2.0 \\
61 \pm 3.0\end{array}$ & $\begin{array}{l}39 \pm 1.5 \\
57 \pm 1.5 \\
59 \pm 4.2\end{array}$ & $\begin{array}{l}35 \pm 3.5 \\
45 \pm 6.7 \\
40 \pm 0.6\end{array}$ & $\begin{array}{l}21 \pm 1.5 \\
25 \pm 4.6 \\
21 \pm 2.0\end{array}$ \\
\hline
\end{tabular}

* Mean of three observations plus or minus standard error.

$\dagger$ Cardiac effect.

There were remarkably small differences among the brain ammonia concentrations when they were determined simultaneously with the blood levels (Table I). The primary toxicity of ammonium hydroxide, which produced the lowest brain level, later was found to be at a different site (vide infra). Although the amounts of $\mathrm{NH}_{4}-\mathrm{N}$ administered as the acetate and bicarbonate salts were less than the amount administered as the chloride salt, the brain ammonia concentration demonstrated a comparative increase in the passage of ammonia into the brain as the $\mathrm{pH}$ increased (Table I).

In order to minimize traumatic factors, which might have increased brain ammonia levels (12), and to determine accurately the entrance of ammonia into the brain in the critical first minute, brain ammonia concentrations were obtained in mice which had not been bled previously. Five seconds following the injection of each salt (Table II), with the exception of ammonium hydroxide, the brain $\mathrm{NH}_{4}-\mathrm{N}$ levels were essentially the same. At 30 and 60 seconds the differences continued to show little relation to the amount administered, except for the brain $\mathrm{NH}_{4}-\mathrm{N}$ concentration of ammonium hydroxide, which remained significantly lower than the other.

It was noted that when ammonium hydroxide was administered, the mice evinced unusual muscular contortions. On palpation immediately following the terminal tonic convulsion, the heart beat showed marked slowing and irregularity. This was contrary to observations of mice given the other ammonium salts. These mice demonstrated no appreciable cardiac abnormalities.

Electrocardiograms were performed during the injection of $\mathrm{LD}_{50}$ doses of the ammonium salts. These demonstrated that ammonium chloride, acetate, bicarbonate, and carbonate had very little cardiac effect other than the production of a slight bradycardia while ammonium hydroxide caused slowing and irregularity, followed by asystole.

\section{DISCUSSION}

A relationship between the lethal dose of ammonia and blood $\mathrm{pH}$ was presented in a previous publication (1). This included a discussion of the literature of ammonia toxicity. In that study the decrease in the lethal dose of $\mathrm{NH}_{4}-\mathrm{N}$ which was associated with an increase in the blood $\mathrm{pH}$ was presumed to be due to an increase in the ratio of $\mathrm{NH}_{3} / \mathrm{NH}_{4}{ }^{+}$, since unionized ammonia $\left(\mathrm{NH}_{3}\right)$ penetrates tissue barriers more easily than ionized ammonia $\left(\mathrm{NH}_{4}^{+}\right)$. Jaquez, Poppell, Lawrence and Roberts (13) followed by Lawrence and associates (14) had previously noted the effect of $\mathrm{pH}$ and temperature on ammonia in terms of the partial pressure of ammonia gas. They hypothesized that ammonia passage into the tissues would be enhanced by increased blood $\mathrm{pH}$.

Milne, Scribner and Crawford (6) have summarized the theoretical and experimental evidence for the nonionic diffusion of weak acids and bases (including ammonia). in the stomach, kidney and pancreas. In general their discussion of diffusion in those organs pertains to the blood-brain-barrier (7-9) which acts similarly as a biological membrane, more permeable to the unionized fraction of weak base than to the ionized fraction.

In this study $\mathrm{LD}_{50}$ doses of ammonium salts produced signs of cerebral intoxication including coma and generalized convulsions. Only one compound, $\mathrm{NH}_{4} \mathrm{OH}$, was shown to have a severe cardiotoxic effect by electrocardiogram. Since the toxic effect of the ammonia appeared to be primarily a cerebral one, the concentration of the 
ammonia in the brain rather than in the blood would appear to be the important factor. If the brain level of ammonia were always a direct function of the blood level, then the latter could be utilized as a measure of ammonia toxicity. However this does not appear to be a constant relationship, particularly when there are variations in blood $\mathrm{pH}$.

As shown in Table $I$, the blood concentration of ammonia does vary directly with the intravenous dosage ; moreover the difference between each dosage appears to be accentuated by differential rates of passage from the blood stream, apparently related to the changes in blood $\mathrm{pH}$. In spite of this the brain levels for all the compounds except $\mathrm{NH}_{4} \mathrm{OH}$ (vide supra) were remarkably similar (Table II). These data indicate that when there are variations in blood $\mathrm{pH}$ there is no direct relationship between blood ammonia concentration and the lethal effect of ammonia. The toxicity of ammonia appears to be cerebral in origin, and the $\mathrm{LD}_{50}$ does correlate with the relatively constant brain concentrations.

The data indicate, further, that a given blood ammonia concentration may be more toxic when the blood $\mathrm{pH}$ is elevated. The practical implications of this problem were discussed by Vanamee and co-workers (15), when they noted [confirmed by Robin and associates (16)] that patients in hepatic coma, usually with elevated blood ammonia concentrations, were frequently in respiratory alkalosis.

The theoretical foundation of this study, based on the effect of $\mathrm{pH}$ on the ionization of ammonia in solution, supports the experimental findings. Calculations were made (1) showing that the ratio of $\mathrm{NH}_{3}$ to $\mathrm{NH}_{4}{ }^{+}$for a given ammonia concentration varied directly with the blood $\mathrm{pH}$. Consequently the quantity of ammonia entering the brain was approximately the same for each salt (except $\mathrm{NH}_{4} \mathrm{OH}$ ) despite significant variations in the amount of $\mathrm{NH}_{4}-\mathrm{N}$ present in the $\mathrm{LD}_{50}$ doses (Table II).

Although the ammonia concentration in the brain of mice at the $\mathrm{LD}_{50}$ appeared to be relatively constant, there were some variations (Table II). For example, 50 per cent of the mice given ammonium carbonate were dead within 15 seconds. Nevertheless, the average brain levels of surviving mice given ammonium acetate and bicarbonate were significantly higher at $60 \mathrm{sec}-$ onds than any levels recorded in the mice which had received ammonium carbonate. Therefore, other factors beyond that of an overall critical toxic ammonia level for the brain must have been present: rate of change, localized changes, and intracerebral $\mathrm{pH}$ alterations might have modified toxicity to a certain degree.

Many investigators (17-21) have examined both peripheral and cerebral arteriovenous ammonia differences in patients with elevated blood ammonia levels. Most of the observations revealed no uptake of ammonia by brain and muscle, although some have shown an ammonia release $(20$, 21). One group (21) has pointed out that all possibilities can occur in patients with high arterial ammonia concentrations, from uptake to equilibrium and finally to release of ammonia by the brain. Determination of blood $\mathrm{pH}$ might have resolved these seemingly inconsistent results. Acidosis might have decreased cellular absorption enough to bring about an equalization of arterial and venous ammonia levels. Alkalosis might have significantly increased tissue uptake.

A relationship between ammonia toxicity and hepatic coma has been established in many patients with liver disease through the administration of high protein diets and oral ammonium salts. Nevertheless, a consistent correlation between the state of consciousness and the blood ammonia level alone (venous or arterial) never has been established. According to our studies the peripheral or cerebral venous ammonia concentration actually may show an inverse relationship to the state of coma. In alkalosis the venous ammonia level may be low in spite of high arterial levels due to increased tissue uptake. In acidosis the reverse could hold. A solution to this problem may be achieved by combining the results of arterial ammonia and blood $\mathrm{pH}$ determinations. A correlation between blood ammonia levels and state of consciousness in some patients in impending coma or frank hepatic coma then may be possible.

\section{SUMMARY}

1. Intravenous $\mathrm{LD}_{50}$. doses of five ammonium salts with different blood $\mathrm{pH}$ effects were injected into mice. Simultaneous blood and brain am- 
monia concentrations and blood $\mathrm{pH}$ 's were determined.

2. In spite of appreciable differences in the $\mathrm{NH}_{4}-\mathrm{N}$ content of the $\mathrm{LD}_{50}$ dose of each salt there were remarkably small differences among the brain $\mathrm{NH}_{4}-\mathrm{N}$ concentrations. The sole exception was ammonium hydroxide, which was shown to be primarily a cardio-toxic rather than a cerebro-toxic drug.

3. The different rates of passage of ammonium salts across the blood-brain-barrier were related to their different effects on blood $\mathrm{pH}$. As the blood $\mathrm{pH}$ was increased by the salt, the amount of unionized ammonia (which easily crosses tissue barriers) increased relative to that of ionized ammonia (which does so poorly).

4. The variable results obtained in brain and muscle arteriovenous ammonia experiments, and the lack of correlation between blood ammonia levels and state of consciousness in hepatic coma patients were discussed.

\section{ACK NOWLEDGMENTS}

The authors would like to acknowledge the thoughtful criticism of Dr. Louis J. Oliver and Dr. Charles G. Zubrod, the technical assistance of Mr. Lewis F. Seibel, and the statistical analysis by Mrs. Lila Knudsen Randolph.

\section{REFERENCES}

1. Warren, K. S The differential toxicity of ammonium salts. J. clin. Invest. 1958, 37, 497.

2. Bates, R. G., and Pinching, G. D. Dissociation constant of aqueous ammonia at 0 to $50^{\circ}$ from $\mathrm{E}$. $\mathrm{m}$. $\mathrm{f}$. studies of the ammonium salt of a weak acid. J. Amer. chem. Soc. 1950, 72, 1393.

3. Albert, S. Selective Toxicity with Special Reference to Chemotherapy. New York, John Wiley \& Sons, 1951, pp. 72-108.

4. Orloff, J., and Berliner, R. W. The mechanism of the excretion of ammonia in the dog. J. clin. Invest. 1956, 35, 223.

5. Brodie, B. B., and Hogben, C. A. M. Some physicochemical factors in drug action. J. Pharm. (Lond.) 1957, 9, 345.

6. Milne, M. D., Scribner, B. H., and Crawford, M. A. Non-ionic diffusion and the excretion of weak acids and bases. Amer. J. Med. 1958, 24, 709.

7. Waddell, W. J., and Butler, T. C. The distribution and excretion of phenobarbital. J. clin. Invest. 1957, 36, 1217.
8. Stabenau, J., Rall, D. P., Gaskins, J., and Zubrod, C. G. Effect of $\mathrm{pH}$ on transfer of drugs from blood to cerebrospinal fluid (abstract). J. Pharmacol. exp. Ther. 1958, 122, 72A.

9. Stabenau, J., Warren, K. S, and Rall, D. P. The role of $\mathrm{pH}$ gradients in the distribution of ammonia between blood and cerebrospinal fluid (CSF), brain, and muscle (abstract). J. clin. Invest. 1958, 37, 933.

10. Nathan, D. G., and Rodkey, F. L. A colorimetric procedure for the determination of blood ammonia. J. Lab. clin. Med. 1957, 49, 779.

11. Nathan, D. G., and Warren, K. S A colorimetric procedure for the measurement of the brain ammonia of the mouse: The effect of glutamine on the total measurable ammonia. Submitted for publication.

12. Richter, D., and Dawson, R. M. C. The ammonia and glutamine content of the brain. J. biol. Chem. 1948, 176, 1199.

13. Jaquez, J. A., Poppell, J. W., Lawrence, W., Jr., and Roberts, K. E. Clinical significance of the partial pressure of ammonia $\left(\mathrm{PNH}_{3}\right)$ in patients with ammonium toxicity (abstract). Clin. Res. Proc. 1957, 5, 20.

14. Lawrence, W., Jr., Jaquez, J. A., Dienst, S. G., Poppell, J. W., Randall, H. T., and Roberts, K. E. The effect of changes in blood $\mathrm{pH}$ on the plasma total ammonia level. Surgery 1957, 42, 50.

15. Vanamee, P., Poppell, J. W., Glicksman, A. S., Randall, H. T., and Roberts, K. E. Respiratory alkalosis in hepatic coma. A. M. A. Arch. intern. Med. 1956, 97, 762.

16. Robin, E. D., Whaley, R. D., Crump, C. H., and Travis, D. M. The nature of the respiratory acidosis of sleep and of the respiratory alkalosis of hepatic coma (abstract). J. clin. Invest. 1957, 36, 924.

17. Bessman, S. P., and Bessman, A. N. The cerebral and peripheral uptake of ammonia in liver disease with an hypothesis for the mechanism of hepatic coma. J. clin. Invest. 1955, 34, 622.

18. Bessman, S. P., and Bradley, J. E. Uptake of ammonia by muscle. Its implication in ammoniagenic coma. New Engl. J. Med. 1955, 253, 1143.

19. Fazekas, J. F., Ticktin, H. E., Ehrmantraut, W. R., and Alman, R. W. Cerebral metabolism in hepatic insufficiency. Amer. J. Med. 1956, 21, 843.

20. Webster, L. T., Jr., and Gabuzda, G. J. Ammonium uptake by the extremities and brain in hepatic coma. J. clin. Invest. 1958, 37, 414.

21. Summerskill, W. H. J., Wolfe, S. J., and Davidson, C. S. The metabolism of ammonia and $\alpha$-ketoacids in liver disease and hepatic coma. J. clin. Invest. 1957, 36, 361. 